\title{
THE EFFECTIVENESS OF THE IMPLEMENTATION OF PRESIDENTIAL INSTRUCTION (INPRES) NO. 5/2019 IN ERADICATING THE PEATLAND FIRES IN THE KALIMANTAN REGION
}

\author{
${ }^{1}$ Renate Septiana Widiaputri, ${ }^{2}$ Sathya Reysha Wacanno, ${ }^{3}$ Syahrir Roni Geyasra \\ ${ }^{123}$ International Relations, Faculty of Social and Political Science, Universitas Kristen Indonesia, Jakarta, \\ Indonesia \\ ${ }^{1}$ renate.widiaputri@gmail.com, ${ }^{2}$ sthreysha@gmail.com, ${ }^{3}$ ronisyahrir@gmail.com
}

\begin{abstract}
The forest and peat permit moratorium is a policy aimed at improving and perfecting the ongoing management of forests and peatlands. The policy also aims to continue efforts to reduce emissions from deforestation and forest degradation. This moratorium policy for forest and peat permits was created during the reign of former President Susilo Bambang Yudhoyono in 2011 and is extended every two years. In 2019, the policy was ordered as a permanent moratorium by President Joko Widodo and formulated in Presidential Instruction No. 5/2019. Since the implementation of the moratorium, there has been a decrease in the rate of deforestation of forests and peatlands in Indonesia. However, forest and land fires still occur, especially in the Kalimantan region. Even in 2019, significant forest and peatland fires have occurred in Kalimantan since a similar incident in 2015. The hotspots of these fires are scattered in various provinces in Kalimantan, disrupting public health due to the thick smoke generated. This study is analyzed using the Theory of Policy Implementation by George C. Edward III. Through policy research, this research is examined qualitatively to analyze the effectiveness of the implementation of Presidential Instruction No. 5/2019 on the phenomenon of peatland fires in the Kalimantan region. The results of this study indicate that there are still weaknesses in implementing Presidential Instruction No. $5 / 2019$, so that it is said to be less effective in eradicating forest and peatland governance.
\end{abstract}

Keywords: Effectiveness, Policy Implementation, Presidential Instruction, Peatland Fires

DOI: $10.33541 /$ sp.v21i3.2264

Sociae Polites : Majalah IImiah Sosial Politik

Faculty of Social and Political Science, Universitas Kristen Indonesia

ISSN 1410-3745 print/ ISSN 2620-4975 online

Volume 21, Number 2 (Youth Peatland Conference)

Pages 221-233 


\section{Introduction}

\subsection{Background}

Peatlands are wetlands that are rich in organic material and have an essential function for human life. The functions of peatlands, among others, are to safeguard climate change, reduce the impact of natural disasters such as floods and drought, support the local community's economy, and as a habitat for biodiversity protection.

Due to the vital function of peatlands, Indonesia, in 2011, under the leadership of former President Susilo Bambang Yudhoyono, imposed a moratorium on forest and peat permits. The moratorium is valid for two years and continues to be extended until 2019 (Samadhi 2019). Forest fires and land fires (Karhutla) decreased by about $20 \%$ within eight years when the moratorium was imposed (Madani 2019, 3).

This statement is one reason for President Joko Widodo's policy regarding the moratorium on new permits for land clearing to become permanent per 2019. This policy is formulated in Presidential Instruction Number 5 of 2019 concerning the termination of granting new permits and improving the management of primary natural forests and peatlands. The purpose of establishing this Inpres is to save the existence of primary natural forest and peatland and reduce emissions resulting from deforestation and forest and land degradation (Kementerian Sekretariat Negara Republik Indonesia 2019).

In fact, Karhutla becomes an annual phenomenon in Indonesia. The worst peatland fires occurred in 2014 in Sumatra and 2015 in Sumatra and Kalimantan. About $80 \%$ of Indonesia's total fires for nearly a decade have occurred in Kalimantan and Sumatra (Yulianit 2015, 11). The Head of the Disaster Management Agency (BNPB) also said that forest and land fires are difficult to extinguish and produce dense smoke, one of which is the burning of large areas of peatland (Arumingtyas 2019).

Figure 1. Fire-Prone Areas of Tropical Forests and Peatlands in Indonesia

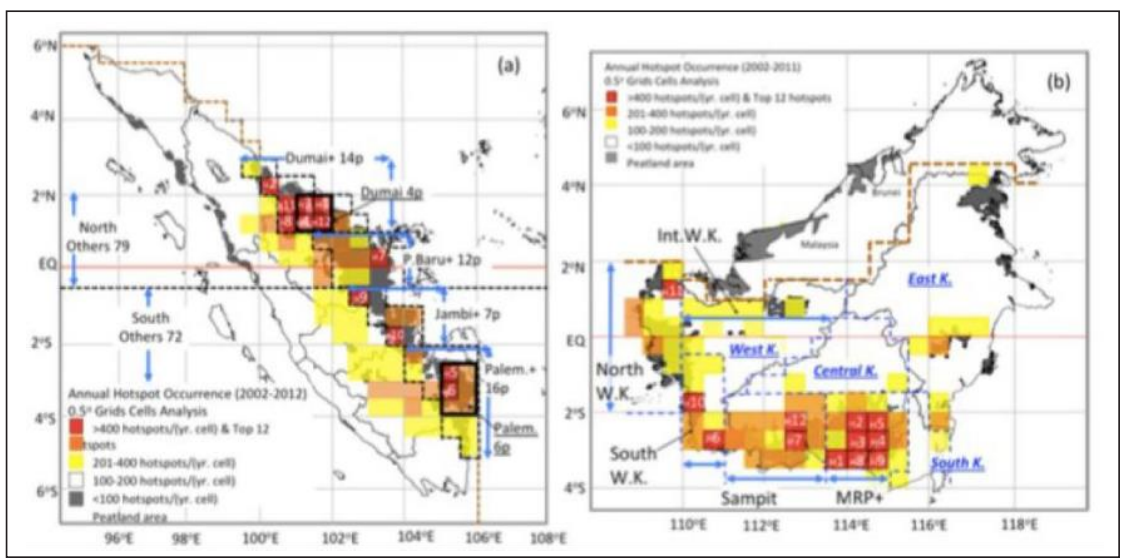

(Source: Yulianit 2015, 11)

From contained anomalous data gathered, the vast increase in land and forest fires in 2019 is an area of 1,649,258 hectares (ha) in Indonesia (Ministry of Environment and Forestry 2020). The increase in forest and land fires in that year required Indonesia to experience an economic loss of IDR 77 trillion (ALMI 2020). Meanwhile, in previous years, there were narrower data on the area of forest fires and land, as shown in Table 1: 
Table. 1 Total Area of Forest and Land Fires (Ha) 2017-2020

\begin{tabular}{|c|c|c|c|}
\hline The Year 2017 & The Year 2018 & The Year 2019 & $\begin{array}{c}\text { The Year 2020 } \\
\text { (Kuartal I) }\end{array}$ \\
\hline $165.483,92$ & $529.266,64$ & $\mathbf{1 . 6 4 9 . 2 5 8}$ & 206.751 \\
\hline
\end{tabular}

(Source: KLHK 2020)

The existence of forest fire fluctuations, according to Table 1, has a great potential to widen deforestation and degradation on peatlands. Seeing from the data quoted from Bambang Hero Saharjo as expert forensics of forest fires at the Bogor Agricultural Institute (IPB), the total area of peatland affected by forest fires in 2019 is $494,450 \mathrm{Ha}$, as much as $482,674 \mathrm{Ha}$ of the total area is a remarkable restoration area (Suwastoyo 2020 ). This area increased three times from the total area of peatland fires in 2018, 125,340 Ha. Central Kalimantan Province is the most prominent spot in peatlands most affected by forest and land fires. As of June 2020, peatland fires have consumed an area of 38,772 hectares ( Ibid, 2020). Karhutla, on a large scale that occurs in Indonesia has various impacts, one of which is haze, which can threaten health. This is not only felt in Indonesia but also in other countries, such as Malaysia and Singapore. So, this problem is not just a national problem, but also a global problem.

Therefore, Policy Number 5 of 2019 is the Jokowi government's effort to reduce forest and land fires in Indonesia. Of course, forest and land fires in Indonesia have decreased, but at several hotspots, there are still $\mathrm{n}$ hotspots that can trigger even more forest and land fires in the future. This triggers researchers to see the effectiveness of Presidential Instruction Number 5 of 2019 policy in dealing with peatland fires. This research focuses on the Kalimantan region, which is a hot spot for forest and land fires. Analysis of policy implementation's effectiveness against forest fires coupled with seeing the red line problems and the implications for different aspects of life, such as the environment and social economy sectors. Later, it will be correlated by dissecting the Inpres policy Number 5 of 2019. The purpose of this paper is to see what needs to be addressed and maintained regarding efforts to tackle peatland fires in Indonesia, particularly in the Kalimantan region.

\subsection{Research Question}

Based on the above background, as for the formulation of the problem raised in this study, namely, "how effective is the implementation of Inpres policy No. 5 of 2019 in tackling peatland fires in the Kalimantan region?"

\subsection{Research Methods}

This policy research is conducted qualitatively by collecting data through a literature review from previous research and government documents. According to Pantjar Simatupang, policy research is a process of synthesizing information, both research results and performance reports, to produce a recommendation for a public policy (Simatupang 2003, 4). Policy research was initiated because of an underlying problem. According to Majchrzak in Supriyadi $(2018$, 152), these problems are processed through research to find recommendations for policymakers. Conducted descriptively from government policies issued with the motivation to provide an overview and guidance for actors with interest in the policy. Policy research is conducted with a general and open scope so that the results can be reevaluated, replicated, and implemented. 


\section{Literature Review}

\subsection{Literature Review}

In Kusharati Budiningsih's research entitled Implementation of Forest and Land Fire Control Policies in South Sumatra Province, it is explained that the forest and land fires that occur in Indonesia have an impact on social, cultural, economic, and political aspects. The Indonesian government then involved multi-government institutions in controlling forest and land fires. In turn, it creates coordination between government agencies. This study used a qualitative approach to analyze coordination between government agencies in controlling forest and land fires, with an example of South Sumatra Province cases. This study also uses coordination theory to analyze processes. This study shows that the coordination that occurs is in the context of forest and land fire suppression. The resulting performance between agencies is less than optimal, which is viewed from the blackout target's achievement. This is due to several factors that influence the coordination process, namely authority, communication, control, and leadership (Budiningsih 2017).

The second research is The Institutional Fit of Peatland Governance in Indonesia by Saritha Kittie Uda, Greetje Schouten, and Lars Hein. This study analyzes the institutional suitability of regulations in Indonesia regarding the use of peatlands and their use characteristics. The research also examines Indonesia's policies and laws regarding the use and management of peatlands. Uda, Schouten, and Hein focused on two provinces, namely Jambi and Central Kalimantan because they have extensive peatlands. The researchers conducted questionnaires and interviews with peatland users and policymakers.

According to Uda, Schouten, and Hein, land policies are often ineffective due to unclear management authority for all peatlands types. Besides, there is a lack of law/policy enforcement at the province, district, and village levels. The research uses institutional theory in management and organization, which says that the institutional context affects legitimate practices and processes. This research shows that many peatland users do not understand regulations related to peatlands. The lack of socialization about the content of regulations and alternative practices for peatlands and the lack of field monitoring and enforcement of public relations are the main factors for non-compliance with peatland regulations (Uda, Schouten and Hein 2018).

The two studies above are different from the current research because this study uses the theory of policy implementation by Edward III. This theory is used to analyze the effectiveness of implementing the Inpres policy No.5 / 2019 in controlling peatland fires. The case in this study focuses on the Kalimantan region because most forest and land fires occurred in 2019, namely in Kalimantan. Referring to the indicators in Edward III's theory, this study links them to implementing the Inpres policy No. 5 of 2019. This study illustrates the Indonesian government's discourse anomalies with the increase in forest and land fires, especially peatlands in Kalimantan in 2019.

\subsection{Theory of Effectiveness of Policy Implementation}

George Edward III, in his writing entitled "Implementation of Public Policy," measures the effectiveness of a policy based on four primary sources (Putra and Khaidir 2019, 238-239), namely:

1) Communication

Communication becomes the next point that needs to be accounted for communication a benchmark to see how policies are disseminated clearly and in a common understanding. Edward III believes that communication has several 
dimensions that need to be considered: first, the transmission is the first judging dimension. Policies must be known by all interested parties, both policy implementers and policy target groups. Second, clarity into a useful dimension to see the makers, implementers, target, and other parties get information related to policies and rules. Seeing the actors involved understand both the intentions, the objectives of the policy substantially. This is so that the actors involved understand the points that become their duties and responsibilities so that they can be implemented harmoniously and clearly in practice. Third, consistency is needed for policy clarity, so there is no confusion regarding the policy. The high effectiveness of policy implementation is influenced by policy implementers' consistency in understanding policy intentions with precision and implementing them.

2) Resources

Edward III said that organizational resources were categorized into staff, information, authority, facilities, buildings, equipment, land, and equipment. Human resources should be adequate both in quantity and quality. The information availability must also be owned by those in charge of implementing policies to carry out policies that have been set by policymakers. The authority that includes and fulfills the responsibilities and obligations and the facilities needed for implementing the policy must also be available for effective implementation. Economically, resources are related to costs. Resources to be developed and implemented are following the objectives of the policies that have been made.

3) Disposition

Disposition refers to the characteristics or character or ethics of the implementers. Examples include commitment, honesty, and democracy. When the actors who play a role - both policymakers, implementers, and target targets - have different perspectives, attitudes, or characteristics, then the policy implementation process becomes ineffective.

4) The Organizational Structure or Workflow of a Bureaucracy

This point is seen based on the standard procedures for implementing government systems and policy rules implementation. Edward III believes that implementing a policy does not work effectively due to the inefficiency of the existing bureaucratic structure. The bureaucratic structure includes bureaucratic structure, division of authority, and relationships between organizational units. Edward III saw that the more fragmentation in a bureaucracy, the more excellent the opportunity for distributing information related to policy. So, when there is much fragmentation, more intensive coordination is needed.

In an illustration, the relationship between the four main sources above to see the effectiveness of policy implementation can be seen in the Graph. 2:

Graph 2. Sources Affecting the Effectiveness of Policy Implementation according to George Edward III

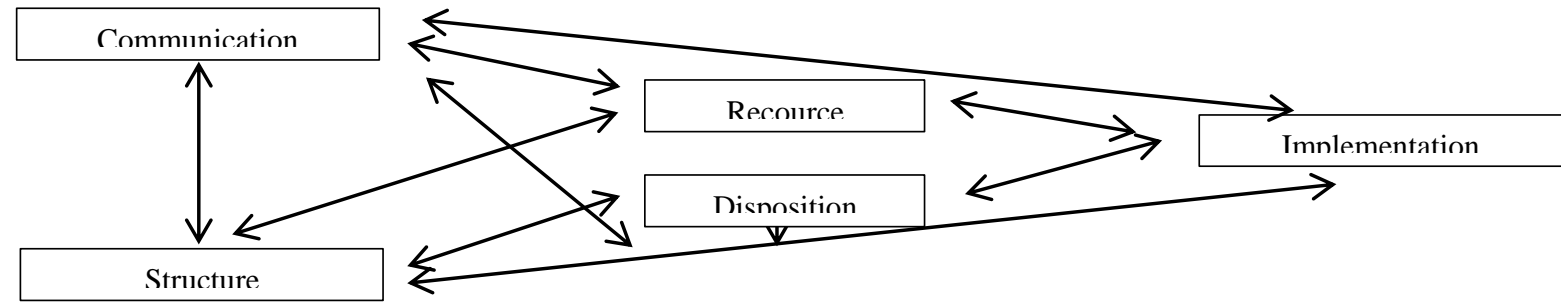

(Source: Widodo 2011, 96 ) 
Through this theory, researchers will see the implementation of the permanent moratorium policy through Inpres No.5 of 2019 regarding peatland fires, which is the focus of the government.

\section{Results and Discussions}

Indonesia's annual phenomenon of forest and land fires is based on various causes, especially peatland fires. As well as being caused by the influence of weather, forest and peatland fires in Indonesia are 99\% caused by human activity (BNPB 2019). Failure to dispose of cigarette sticks, burn rubbish, and clear land to meet their daily needs has triggered the spread of the majority of Karhutla. The increasing spread of the burned peat area results from the spreading and abundance of fire sources or hotspots that are difficult to extinguish. As explained above, Kalimantan is one of the peat areas that is heavily affected by fires. The distribution of the area of peat fires in the Kalimantan region in 2019 can be seen in Table 2:

Table.2 Spread of Peatland Fires in Kalimantan Region The year 2019

\begin{tabular}{|c|c|c|c|c|}
\hline \multicolumn{5}{|c|}{ Area (Unit of Ha) } \\
\hline $\begin{array}{c}\text { North } \\
\text { Kalimantan }\end{array}$ & $\begin{array}{c}\text { South } \\
\text { Kalimantan }\end{array}$ & $\begin{array}{c}\text { Central } \\
\text { Kalimantan }\end{array}$ & $\begin{array}{c}\text { East } \\
\text { Kalimantan }\end{array}$ & $\begin{array}{c}\text { West } \\
\text { Kalimantan }\end{array}$ \\
\hline 5 & 11.950 & 183.836 & 5.673 & 60.487 \\
\hline \multicolumn{5}{|c}{ Total = 261.950 Ha } \\
\hline
\end{tabular}

(Source: KLHK 2019)

Looking at the data above and correlated with data in the background, more than half of Indonesia's total peat burning area is in the Kalimantan region. Of the five provinces in the Kalimantan region, Central Kalimantan Province is the most affected.

Inpres Number 5 of 2019, a continuation of the previous INPRES, is intended to address problems related to the sustainability of forests and peatlands in Indonesia. The content of INPRES Number 5 of 2019 consists of an order to stop the granting of new permits for forest and land areas in Indonesia with the assignment of tasks and responsibilities to government agencies. The tasks and responsibilities focused on the Ministry of Environment and Forests that also integrate with the Ministry of the Interior, the Ministry of Agricultural and Spatial Planning, Ministry of Agriculture, Ministry of Public Works and Housing, Head of the Geospatial Information Agency, governors, regents, and mayors d nature of policy implementation this. The integration between government agencies and field implementers is reported by the Ministry of Environment and Forestry every six months to the President. Including update the Indicative Map New License Termination (PIPPIB). Flow execution of this Presidential Instruction dip Antau by the Secretariat of the Cabinet.

The effectiveness of Presidential Instruction No. 5 of 2019 can be viewed using the theory by George Edward III is associated with the phenomenon of peatland fires in Kalimantan. According to the previous explanation, the following four primary sources to see the effectiveness of policy implementation:

\section{1) Communication}

Inpres Number 5 of 2019, which is a continuation of the previous year's moratorium, is one of the government's efforts to map the problem's root. The government sees various violations in forest and peatland areas, one of which is a lack of management mapping related 
to land use and forest product utilization permits. This instruction was issued to fix and improve the management of permits for natural forests and peatlands by conducting land consensus, which is included in the PIPPIB. KLHK is responsible for updating the PIPPIB.

Top-down communication is a starting point explored. The ministries appointed are responsible for synergizing with local governments to conduct socialization related to this rule practically. The Ministry of Environment and Forestry itself coordinates with Regional Governments (Pemda), Governors or Mayors, and the Environment and Forestry Service in the regions, particularly in the Kalimantan region. Land governance is the focus of the government to tackle and mitigate the forest and land fires phenomenon. As stated in the third dictum number one, the Ministry of Environment and Forestry has the responsibility to stop granting new permits, increase the effectiveness of managing critical land through ecosystem restoration, replanting and land restoration to reduce emissions from peatlands.

Furthermore, the Ministry of Environment and Forestry is responsible for revising the PIPPIB every six months in coordination with other ministries and non-governmental institutions (Ministry of State Secretariat of the Republic of Indonesia 2019, 3). As a continuation and improvement of the instructions issued, the Ministry of Environment and Forestry issued Decree of the Minister of Environment No: SK.7099 / MENLHK-PKTL / IPSDH / P.LA.1 / 8/2019, which was renewed in 2020 to NO: SK.851 / MENLHK- PKTL / IPSDH / PLA.1 / 2/2020. The Decree (SK) is a reference for Governors and Regents / Mayors to issue recommendations and issue new location permits based on the PIPPIB, as stated in the Tenth Amendment (KLHK 2020).

This illustrates the existence of three dimensions that have been implemented and attempted by transmitting the executors to know the contents of the instructions issued. In the next stage, the executors, namely the relevant ministries - notably the KLHK - issued a decree as a continuation and refinement of INPRES Number 5 of 2019. At the same time, the issuance of this decree illustrates a common understanding. Furthermore, this decree will become a reference for the regional government in regulating licensing governance, which is considered to be the root that must be addressed so that forest and land fires can be resolved. The consistency of this practice at the central level of government institutions is illustrated in this explanation. However, in the regional realm, from the data collected from Madani (Madani 2020), 31.35\% of forest and land fires in Indonesia occurred in the PIPPIB area in 2019 and designated as peatlands Ecosystem Functions were the areas most affected. This is due to the overlapping of plantation and industrial land concessions.

\section{2) Resources}

In this section, the resources examined are grouped into three, namely:

a) Human Resources (HR)

In the process of implementing the rules that have been made, according to Edward III, sufficient human resources are needed both in quantity and quality for the effectiveness and efficiency of policy implementation. In the case of implementing INPRES No.5 of 2019 regarding peatland fire in the Kalimantan region, there are several advantages and obstacles related to the number of human resources owned. Orderly management of permits and legal firmness on the issue of violations that cause forest and land fires are parts that need to be addressed and become one of the responsibilities of the Environmental and Forestry Law Enforcement and Protection Agency (BPPHLHK), which is spread across various regions in Indonesia, one of which is Kalimantan.

The BPPHLHK in the Kalimantan region reports that human resources' potential will increase significantly, given the joining of two ministries to become KLHK (B. BPPHLHK 2020, 7). Then, the expertise related to peat has also increased with the establishment of the Peat Restoration Agency. Based on the Ministry of Environment and Forestry's report 
regarding the revision of $\mathrm{P}$ IPPIB for the second period of 2020, to implement the peatland consensus, the central government included peat experts from various lines, such as academics and practitioners.

The BPPHLHK work unit in the Kalimantan region has a total of 191 employees. BPPHLHK Kalimantan sees this number as a potential and, at the same time, becomes an obstacle because the apparatus at the basic level is sufficient for the socialization of existing laws. However, at the operational level, the required personnel resources are insufficient compared to the obstacles faced. The total number of BPPHL employees is spread across several areas, namely:

Table 3. Distribution of BPPHLHK Human Resources in Kalimantan Region in 2016-2019

\begin{tabular}{|c|l|c|c|c|c|}
\hline No. & \multicolumn{1}{|c|}{ Work Unit } & $\mathbf{2 0 1 6}$ & $\mathbf{2 0 1 7}$ & $\mathbf{2 0 1 8}$ & $\mathbf{2 0 1 9}$ \\
\hline $\mathbf{1 .}$ & $\begin{array}{l}\text { BPPHLHK } \\
\text { Kalimantan Region }\end{array}$ & 14 & 13 & 17 & 16 \\
\hline $\mathbf{2 .}$ & $\begin{array}{l}\text { Section I } \\
\text { Palangkaraya Region }\end{array}$ & 45 & 45 & 51 & 52 \\
\hline 3. & Section II Samarinda & 46 & 49 & 64 & 64 \\
\hline 4. & Section III Pontianak & 54 & 55 & 57 & 59 \\
\hline & TOTAL & $\mathbf{1 5 9}$ & $\mathbf{1 6 2}$ & $\mathbf{1 8 9}$ & $\mathbf{1 9 1}$ \\
\hline
\end{tabular}

(Source: BPPHLHK 2019, 12)

In the implementation of duties based on the function of the position, in 2019 the number of human resources in each work unit is divided into:

a. BPPHLHK Kalimantan Region

This work unit has one (1) Head of Regional Office, one (1) Head of SubDivision, four (4) staff, one (1) PPLH, one (1) Procurement, and eight (8) Contractors or Government Employees with a Work Agreement (P3K).

b. Section I Palangkaraya Region

The work unit in the region I has one (1) Section Head, four (41) Forest Police (Polhut), three (3) PPLH, one (1) staff, and six (6) P3K personnel.

c. Section II Samarinda

The work unit in Region II has one (1) Head of Section, 46 Forest Police, eight (8) PPLH, two (2) staff, and seven (7) P3K personnel.

d. Section III Pontianak

The work unit in region III has one (1) Head of Section, 47 Forest Police, four (4) PPLH, one (1) staff, and six (6) P3K personnel.

Based on the report, the obstacles faced were implementing surveillance and enforcement of criminal law against forest and land fires perpetrators. This is due to the insufficient quantity and quality of Civil Servant Officers (PPNS) and Environmental Monitoring Officers (PPLH) assigned to supervise and investigate forest and forest fire perpetrators. So, it is concluded that the overall human resources at the Ministry of Environment and Forestry in quantity can be said to be sufficient because it is seen from year to year there is an increase in the number of human resources. However, the allocation of labor in the operational realm that is not evenly distributed is considered unable to meet and resolve the practical conditions in the field. 


\section{b) Legal Resources}

With the issuance of Inpres Number 5 of 2019 and the follow-up from the Ministry of Environment and Forestry, issuing a decree to improve regulations provides an expansion of authority for law enforcers. Ideally, the implementation of policies will be carried out effectively when there is a continuity of rules.

However, related to the quality or rigor of instruction and decree that the generated right, both do not have strength in hu k um criminal. Thus, when the Regional Government exercises its authority regarding sanctions and investigations of cases of violations stipulated in Law No.32 of 2019, the majority of cases prosecuted are limited to administrative sanctions, namely prohibiting land use for 3-5 years. As in West Kalimantan Province, in 2019, the West Kalimantan Provincial Government (Pemprov) issued warning letters to 158 companies suspected of violating and causing land fires. These companies were threatened with administrative sanctions. In addition to standard firmness, the law enforcement process has obstacles related to data availability and information relating to business and industrial licenses. The lack of transparency of information to access creates obstacles for the public to monitor the running of this regulation and for non-governmental organizations that can monitor and mitigate perpetrators of violations. Thus, the Kalimantan BPPHLHK stated that law enforcement's capacity in the regency area is at the lowest index value. On the one hand, the achievement index at the center has a high value. This is seen to be an obstacle due to the gap in the index value given between the central and regional governments, which gives a clear picture of not updating the rules, and their respective roles are uniform (BPPHLHK 2019, 8).

Furthermore, INPRES Number 5 of 2019 has exceptions related to areas that are included in the PIPPIB. One of the exceptions is related to government-regulated interests in the Second Dictum points G and H. More clearly, these two exceptions are related to the preparation for developing the central government and infrastructure, which are national strategic projects stipulated by a Presidential Regulation and the improvement of existing infrastructure ( State Secretariat 2019, 2). However, the instructions and SK KLHK related to this exemption, it does not explain the details or area criteria that can be an exception for the benefit of the state and the maximum area included in the exception. Given, the meaning of gray interests can be an opening for each institution's sectoral ego violations that fall into the exception.

c) Budget Resources and Facilities

The budget required to combat forest and land fires is quite large. However, there was a decrease in the budget allocation for forest and land fire control at the Ministry of Environment and Forestry in 2019. For costs, the budget for forest and land fire control in KLHK in 2019 decreased by 70 billion rupiahs from last 2018. In 2018 the budget for forest and land fires was 165 billion in the Ministry of Environment and Forestry Control Directorate, while in 2019, the budget was cut to 95 billion rupiahs. The decline in budget allocations was due to adjustments to forest and land fire cases, which were declared to continue to decline every year (Faizah 2019). However, budget allocations have also been disbursed to other ministries/agencies' directorates following the portion of their primary duties and functions.

\section{3) Disposition}

Disposition can be linked to the existence of interests between agencies that are not compatible. The differences between the central government and the regions contained in the eleventh letter d Ministerial Decree Number: SK. 851 / MENLHK-PKTL / IPSDH / PLA.1 / 2/2020 concerning Determination of Indicative Map of Termination of Granting of New Permits. It is said that the Indicative Map does not apply to land belonging to individual 
communities in other areas of use (APL) as long as it has proof of ownership issued before the Decree of the Minister of Forestry Number SK.323 / Menhut-II / 2011. However, in the 2020 BPPHLHK Kalimantan Work Plan report, it is said that there is a paradigm shift by the government regarding providing excellent access to the community. The granting of this access resulted in many illegal forest occupations. Providing excellent access to the community must also be considered, considering that the forest and land fire cases also come from individuals. As of August 2020, 121 people were named suspects in the forest and land fire case in Indonesia. It is stated that there were 12 cases in the Central Kalimantan Regional Police, which burned an area of 206,406 hectares (Rahma 2020).

\section{4) Bureaucratic Structure}

The government, in Presidential Instruction No. 5/2019, implemented topdown and multi doors. Based on the BPPHLHK Kalimantan report, the public still has difficulty accessing information. This must be corrected so that the public can also participate in combating forest and land fires through a whistleblower mechanism, social control, complaints, and participation in the chain of supervision in the context of enforcing administrative law. The report also states that coordination and synergy between work units, especially the Directorate General, which has the authority to issue permits and establish environmental and forestry legal regulations (B. BPPHLHK 2020, 8). So, suppose it is related to the effectiveness of the implementation of Edward III. In that case, this rule is much segmented in the sustainability of regulations from the center to the regions and many bureaucratic flows that must be passed when there is a punishment in the regions. It can be said that the bureaucracy is not implemented effectively because there are many doors and bureaucracy that must be passed, including permits, law enforcement in the issue of handling peatland fires in the region, especially the Kalimantan region.

\section{Conclusions and Recommendations}

Based on the aspects described above, the implementation of Presidential Instruction No.5 / 2019 on the issue of peatland fires cannot be said to be effective, and there are still shortcomings. As in the communication aspect, which is not yet comprehensive in its topdown delivery, insufficient quality and quantity of human resources, non-binding laws so as not to cause a deterrent effect, budget cuts which if considered are not in line with the increasing cases of forest and land fires in 2019, a commitment the government in eradicating forest and land fires which is quite weak, seen from the overlapping regulations, as well as the fragmented bureaucratic structure that makes it difficult to coordinate between work units. The constraints experienced in every aspect are mutually sustainable, according to Edward III's Public Policy Theory. Therefore, the recommendation that can be given is that there is a need for transparency of information and data related to land use permits, land conversion, and revision of the PIPPIB, along with the reasons for the reduction or increase in the PIPPIB area. It is then necessary to have the criteria for usable land, the maximum area associated with the exceptions regulated in Inpres No. 5/2019 the second dictum from points G and H. Then there needs to be binding, and criminal law has sanctions against parties involved in forest and land fires cases. The central government must also be able to synergize with the Kalimantan regional government and local communities. There is a need for up-to-date uniform task boundaries between the central and regional governments so that there is no gap in the index value of supervision and law enforcement in peatland fires, with the formation of regulations with specific duties and strict administrative and criminal laws. 
That way, those who implement policies made by policymakers have clear and nonoverlapping work mechanisms. This will also impact officers who carry out investigations so that there will be sanctions that will have a deterrent effect and the actions taken against forest and land fire actors have a clear legal basis. 


\section{BIBLIOGRAPHY}

\section{Books}

Yulianit, Nina. 2015. Pengenalan Bencana Kebakaran dan Kabut Asap Lintas Batas (Studi Kasus Eks Proyek Lahan Gambut Sejuta Hektar). Bogor: PT Penerbit IPB Press.

Widodo. 2011. Analisis Kebijakan Publik: Konsep dan Aplikasi Analisis Proses Kebijakan

Publik. Malang: Bayu Media.

\section{Government Documents}

Kementerian Sekretariat Negara Republik Indonesia . Instruksi Presiden Republik Indonesia Nomor 5 Tahun 2019. Dokumen Pemerintah, Jakarta: Kementerian Sekretariat Negara Republik Indonesia, 2019.

KLHK, Kementerian Lingkungan Hidup dan Kehutanan. 2020. Keputusan Menteri Lingkungan Hidup dan Kehutanan Republik Indonesia Nomor: SK.851/MENLHKPKTL/IPSDH/PLA.1/2/2020. Goverment Documents, Jakarta: Kementerian Lingkungan Hidup dan Kehutanan Republik Indonesia.

\section{Journals and Articles}

Budiningsih, Kushartati. 2017. "Implementasi Kebijakan Pengendalian Kebakaran Hutan dan Lahan di Provinsi Sumatera Selatan ." Jurnal Analisis Kebijakan Kehutanan Vol. 14 No. 2 165-186.

Mubarok, Syahrul, et al. 2020. "Policy Implementation Analysis: Exploration of George Edward III, Marilee S Grindle, and Mazmanian and Sabatier Theories in the Policy Analysis Triangle Framework." Journal of Public Administration Studies 34.

Putra, Roby Hadi, and Afriva Khaidir. 2019. "Concept of George C. Edwards III on Implementation of Regional Regulations No. 12 of 2017 Concerning Youth in Granting Youth Service in West Sumatera." International Journal of Progressive Sciences and Technologies (IJPSAT) 238-239.

Simatupang, Pantjar. "Analisis Kebijakan: Konsep Dasar dan Prosedur Pelaksanaan." Analisis Kebijakan Pertanian Volume 1 No.1 Maret, 2003: 1-21.

Uda, Saritha Kittie, Greetje Schouten, and Lars Hein. 2018. "The institutional Fit of Peatland Governance in Indonesia." Land Use Policy 1-8.

\section{Reports}

ALMI , Akademi Ilmuan Muda Indonesia. Riset Tunjukkan Cara Baru Penyelamatan Lahan Gambut yang Bisa Menguntungkan Masyarakat Sekaligus Mencegah Kebakaran Hutan. September 27, 2020. https://almi.or.id/2020/09/27/riset-tunjukkan-cara-barupenyelamatan-lahan-gambut-yang-bisa-menguntungkan-masyarakat-sekaligusmencegah-kebakaran-hutan/ (accessed October 08, 2020 ).

Berkelanjutan, Yayasan Madani. 2019. Catatan Kritis Inpres Nomor 5 Tahun 2019 tentang Penghentian Pemberian Izin Baru dan Penyempurnaan Tata Kelola Hutan Alam Primer dan Lahan Gambut. Catatan, Yayasan Madani Berkelanjutan. 
BPPHLHK, Balai Pengamanan dan Penegakan Hukum LHK. 2020. "Rencana Kerja 2020." Work Plan, Balai Penggamanan dan Penegakan Hukum Lingkungan Hidup dan Kehutanan, Kementerian Lingkungan Hidup dan Kehutanan, 1-27.

Laporan Kinerja Balai Pengamanan dan Penegakan Hukum Lingkungan Hidup dan Kehutanan Wilayah Kalimantan Tahun 2019. Yearly Report, Samarinda: BPPHLHK Kementerian Lingkungan Hidup dan Kehutanan, 2019.

Kementerian Lingkungan Hidup dan Kehutanan. Rekapitulasi Luas Kebakaran Hutan dan Lahan (Ha) Per Provinsi di Indonesia Tahun 2015-2020. Grafik, Jakarta: SiPongi, 2020.

Madani. 2020. Diserbu Titik Api: Ulasan Kebakaran Hutan dan Lahan 2019 serta Area Rawan Kebakaran 2020. May 14. Accessed Oktober 21, 2020. https://madaniberkelanjutan.id/2020/05/14/diserbu-titik-api-ulasan-kebakaran-hutandan-lahan-2019-serta-area-rawan-terbakar-2020.

Yayasan Madani Berkelanjutan. 2019. Catatan Kritis Inpres Nomor 5 Tahun 2019 tentang Penghentian Pemberian Izin Baru dan Penyempurnaan Tata Kelola Hutan Alam Primer dan Lahan Gambut. Catatan, Yayasan Madani Berkelanjutan.

\section{Thesis}

Supriyadi, Dikdik. Analisis Implementasi Kebijakan Pengadaan Kepala Sekolah di Kabupaten Sukabumi. Thesis, Bandung: Universitas Pendidikan Indonesia, 2018.

\section{Websites}

Arumingtyas, Lusia. 2019. Bencana Asap di Sumatera dan Kalimantan, Mengapa Lahan Gambut Terus Terbakar? September 15. Accessed October 9, 2020. https://www.mongabay.co.id.

BNPB, Badan Nasional Penanggulangan Bencana. 2019. 99\% Penyebab Kebakaran Hutan dan Lahan adalah Ulah Manusia. Maret 4. Accessed Oktober 19, 2020. https://bnpb.go.id/berita/99-penyebab-kebakaran-hutan-dan-lahan-adalah-ulahmanusia\#: :text=99\%25\%20Penyebab\%20Kebakaran\%20Hutan\%20dan\%20Lahan\% 20Adalah\%20Ulah\%20Manusia,-

Senin $\% 2 C \% 204 \% 20$ Maret\&text=BENGKALIS\%20\%2D\%20Kebakaran\%20hutan\% 20dan\%20lahan,lahan\%2C\%.

Faizah, Nur. 2019. Anggaran Pengendalian Kebakaran Hutan dan Lahan KLHK Turun Drastis. August 8. Accessed October 29, 2020. https://ekonomi.bisnis.com.

Nasution, Rahmad. 2019. 34 land and forest fire in W Kalimantan involve individuals and company. August 19. Accessed October 20, 2020. https://kalsel.antaranews.com.

Rahma, Andita. 2020. 121 Orang Menjadi Tersangka Kebakaran Hutan dan Lahan. September 5. Accessed October 29, 2020. https://nasional.tempo.co.

Samadhi, Nirarta. 2019. Jokowi telah Berlakukan Permanen Moratorium Izin Hutan. Ini Tiga Keuntungannya bagi Indonesia. Agustus 22. Accessed October 8, 2020. https://wriindonesia.org.

Suwastoyo, Bhimanto. Prevention, Peat, Focus of Indonesia's Forest and Ground Fire Handling in 2020. 15 August, 2020. https://theforestscribe.id/prevention-peat-focusof-indonesias-forest-and-ground-fire-handling-in-2020/ (accessed October 08, 2020) 